\title{
Remnants of Manshūkoku (Manchukuo): Imamura Eiji, Korean Identity under Japanese Imperialism, and Postcolonial Asian Studies*
}

\author{
Joshua Lee Solomon**
}

One of the perennial themes of Manshū (Manchuria) ${ }^{1}$ discourse is that of memory. Manshū existed largely as an image-sometimes fantastic and dreamlike, and surprisingly enduring-produced through a mix of

* This paper is based on presentations given at the 70th Midwest Conference on Asian Affairs, 2021, and the Southwest Conference on Asian Studies, 2021.

** Lecturer, Center for Liberal Arts Education and Practice, Hirosaki University, Japan

1 I diverge from conventional use of Chinese placenames in this paper the reason that its subject is largely concerning the role of language and identity in empire. By using Japanese readings of names and places I do not legitimize or prioritize the Japanese role in the region, but rather acknowledge the perspective and experience of the subjects of my study. Imamura Eiji, by some (Japanese) accounts, was not a proficient Korean speaker, and wrote and communicated only in Japanese. His readers consumed literature and communicated in Japanese. He therefore participated in the literary production of Manshū as place from the perspective of a Japanese language speaker. As Doreen Massey theorized, place is constructed through social relations and encapsulates elements of time and space; thus, "social relations of space are experienced differently, and variously interpreted, by those holding different positions as part of it." Manshūkoku as place substantively differed from "Manzhouguo" or "Manchukuo." By opting for Japanese readings, I hope to nag the reader into recognizing the limitations of the perspective built into Imamura's writing as well as my own Japanese-centric approach to it. Doreen Massey, Space, Place, and Gender (Minneapolis: University of Minnesota Press, 1994), 3. 
state propaganda and popular utopian discourse, despite enjoying only a relatively brief and tortured existence as a modern state before being rapidly dismantled in the aftermath of Japan's total surrender. One of the consequences of the hasty repatriation operation and postwar replacement regime was the destruction and loss of history. ${ }^{2}$ One such casualty is the life detail of one Imamura Eiji (1911-?), a supporting player in the Manshūkoku-period Japanese language literary infrastructure and sometimes literary contributor. His extant record consists of a scant 12 publications, about half of which have enjoyed recent reprints. ${ }^{3}$ But the bulk of Imamura's story - the specific context of his writing and his life in the aftermath of the war-is an ephemeral memory, retained in but few personal and often second-hand recollections.

One reason Imamura intrigued historical readers and has attracted the attention of contemporary scholars is the intersection between his identity and literary works. Imamura was born an ethnic Korean under Japanese occupation, and his writing has been read as an enactment of the personal struggle between his competing national and cultural identities and his internalization of Japanese-supremacist imperializing education. In the following pages, I read through two of Imamura's short stories and consider extant scholarship on his work through a lens aimed at elucidating his colonial poetics as well as highlighting some of the complexity of conducting postcolonial research in the field of Asian area studies and wartime literature. As Imamura's most recognized and praised work "Travel Companions" [dōkōsha], scholarship on it, and his personal (and partially imagined) biography all heavily intersect, I will begin by outlin-

2 Additionally, what records and resources still survive have often been kept locked away in archives by the Chinese government, away from the eyes of contemporary researchers. The lockdown on resources has begun to change only in recent years. Norman Smith, "Postscript," in Manchukuo Perspectives: Transnational Approaches to Literary Production, ed. Norman Smith and Annika A. Culver, 294-300 (Hong Kong: Hong Kong University Press, 2019).

3 Nishida Masaru, "Imamura Eiji no naishin no sekai: 'Shindai' no kaidai wo kanete," Shokuminchi bunka kenkyū, 4 (2005): 191-2. 
ing the plot and themes of the short story before introducing its author and historical context. Then I will introduce a second work, "A New Womb" [shindai], in English for the first time. After contrasting the poetic effects of these two works, I conclude by proposing to read Imamura as mobilizing a kind of minor style - a type of writing marked by strategic ambivalence and repurposing of politically-dominant narratives-observable across many different works of Japanese-language Manshū literature.

My approach follows in part from the words of Manshū writer Kitamura Kenjirō and postcolonial scholar Elleke Boehmer. In 1943, Kitamura suggested that "Manshūkoku...is a production nation [seisankoku]" that requires a " production literature' [seisan bungaku]...."4 My readings in the region of northeastern China known within the Japanese empire of the first half of the twentieth century as Manshū and Manshūkoku (Manchukuo) are often guided by a question of what is being produced (e.g. nationalistic discourses of new "spiritual homes" for Japanese migrants, ethnic categories, a uniquely "continental literature," etc.). However, in the present paper, I want to consider how it is produced. Boehmer's writing of "postcolonial poetics" was the impetus for this redirection. This poetics, she argues, constitutes an aesthetic medium for political engagement. She argues that poetics (structures and figures) are elements of a text with which the reader interacts, spontaneously generating meaning. Politicality is not an inherent attribute: for a text to be political (e.g. to "resist"), its politics must be realized through the act of reading itself. ${ }^{5}$ This strong literary approach, focused on writing technique, offers evidence to support the thematic, historical, cultural, and otherwise contextual elements of critique so central to literature in area studies. Thus, in the following pages, I will step off from Kitamura's appeal to a "production literature," and seek to uncover the "how" that carried the "what"

4 Cited in Kawamura Minato, Bungaku kara miru 'Manshū': 'Gozoku kyōwa' no yume to genjitsu (Japan: Yoshikawa kōbunkan, 1998), 44-45.

5 Elleke Boehmer, Postcolonial Poetics: 21st-Century Critical Readings (Oxford: Palgrave MacMillan, 2018), 2-4. 
toward its ends. Due to space limitations, however, I must keep the following reading extremely narrow.

\section{"Travel Companions"}

Imamura's first and perhaps only major literary success, "Travel Companions," was published in Manshū Administration [Manshū gyōsei] in June 1938 before being immediately reprinted in the inaugural edition of Manshū Romance [Manshū roman] and then Manshū Literary Arts Yearbook [Manshü bungei nenkan] during the same year. ${ }^{6}$ It was deemed significant enough to be included in the recent War and Literature Collection Volume 16: The Light and Shadows of Manshū [Korekushon Sensō to bungaku 16: Manshū no hikari to kage], one of the few contemporary anthologies of Japanese-language Manshū literature.

The story of "Travel Companions" is told from the perspective of a young man I refer to as Shin Jūkin. ${ }^{7}$ Shin is ethnically Korean but was born under Japanese occupation and grew up receiving imperializing education. In the final pages of the story, he recalls that, as a child, he was counseled by his father that their family was fully Japanese and ought to aspire to the ideals of that lofty nationality. This perspective was immediately countered by Shin's older brother, who argued that Japan forced itself upon Korea, and that they must resist its cultural imposition. This contradiction forms the core of the story.

The action of the narrative begins many years later, at the end of $\mathrm{Au}$ gust 1931. The stage is set between the Manpōzan Incident (July 31) and the Nakamura Incident (June 27) on the one hand, and the Manshū Inci-

6 All references are made here to the Manshu roman version. Imamura Eiji, "Dōkōsha" [Travel Companions] Manshū roman, 1 (2002 [1938]): 61-84.

7 Significant portions of this paper are dedicated to explaining the complexities of this decision to use the Japanese reading of the kanji instead of a romanization of the Korean. 
dent (September 18) on the other. The Manshū Incident led directly to the founding of Manshūkoku the following year. The other two incidents involved fatal confrontations in the region marked by violent Chinese reactions to Japanese incursion and were played up in the contemporary media on both sides of the conflict, agitating tensions between China and Japan. The Manpōzan Incident saw a deadly clash between Korean immigrants and Chinese farmers over the construction of an irrigation system and resulted in the Japanese Kantō army opening fire with machine guns into the crowd of Chinese farmers. ${ }^{8}$ The Nakamura Incident was incited by Japanese army captain and intelligence agent Nakamura Shintarō and a small company of men including a Russian and a Mongolian engaging in a covert mission for the Kantō Army. They were traveling along the Chinese Eastern Railway throughout northeastern China and Inner Mongolia until being discovered by the warlord Zhang Xueliang's troops and summarily executed.

In "Travel Companions," Shin has reached some unspecified impasse in his life in Dairen (Dalian) in southern Manshū and is temporarily staying in a Korean inn in Chōshun (Changshun, soon to be Shinkyō/Xinjing, the capital of Manshūkoku) before continuing his journey to the northern reaches of Manshū to live with his brother on a farm. (Geography is another important point which I shall pick up again in the pages below.) In Chōshun, Shin is confronted by a Korean innkeeper who acts offended by Shin's adoption of Japanese dress and language. He informs his guest of a Japanese traveler returning north seeking a Korean travel companion, so Shin makes his final preparations for departure. Fearing an unpleasant encounter with Chinese so-called "bandits" beyond the reaches of the Japanese-dominated city, he gives away all of his Japanese personal effects to the inn's porter and changes into a shabby set of Chinese laborer ("coolie") clothing. When he arrives at the stables, he is surprised to be

8 For some examples of contemporary media leveraging this incident politically, see Yu Sujŏng, “'Jinmin' to 'futei senjin': Imamura Eiji 'Dōkōsha' ni miru minzoku/imin/teikoku," Nihongo to Nihon bungaku, no. 42 (2006): 66-67. 
met by an elderly Japanese man in Korean dress. Shin in a way is following Captain Nakamura's treacherous trajectory toward the (allegedly) lawless northern frontier-including his preoccupation with the "bandits" who ultimately took Nakamura's life. Although it is uncertain whether Imamura was aware, Nakamura would have been traveling in Mongolian clothing at the time of his apprehension, just as Shin outfits himself in an alternative ethnic costume. Furthermore, Nakamura traveled with an ethnically mixed party, just as Shin takes up with a Japanese companion and (presumably) Chinese cart drivers.

The Japanese man explains that rather than the Chinese bandits Shin fears, he is more concerned about encountering "lawless Koreans" [futei senjin] — or anti-Japanese resistors, depending on one's point of view. ${ }^{9}$ Left with no other options, they agree to travel together. Upon clearing the outskirts of the city, however, they are confronted by a group of mounted Korean men dressed in Chinese clothing. The Japanese man suspects Shin to be an informer and pulls a pistol on him. Shin wrestles the weapon away, and the story ends with him aiming it at the attackers while wiping tears from his eyes. The tale ends abruptly, with no clear resolution to his conundrum.

\section{Imamura Eiji}

The clear themes of ethnic identity and imperialization [kōminka] at play in this text have strongly colored considerations of Imamura himself.

9 It bears mention that "Travel Companions" was censored in publication in only one instance, ostensibly a reference to Korean freedom fighters. The text-words spoken by the Japanese travel companion — reads "In Heijō [Pyongyang] they say that many XXXXXXXX Koreans....” In The Light and Shadows of Manshū reprint, however, the censored part is glossed with the words "Chinamen [Shinajin] were killed by." Imamura Eiji, "Dōkōsha," Korekushon Sensō to bungaku 16: Manshū no hikari to kage, 61-84, ed. Asada Jirō, Okuizumi Hikari, Kawamura Mintao, et al (Japan: Shūei-sha, 2012 [1938]), 75. 
According to the author introduction in the anthology The Light and Shadows of Manshū (2012), Imamura was born in Chōsen under the name 長喚基=チャンフワンギ=Jang Hwan-ghi (Chang Hwan-gi), and the years of his birth and death remain obscure. ${ }^{10}$ Yu Sujǒng (2006) suggests that Imamura was born in 1911, but no specific citations are given in either instance. ${ }^{11}$ Imamura was raised under Japanese cultural hegemony in a context highly incentivizing the adoption of Japanese language and customs (although predating the height of cultural enforcement), married a Japanese woman from Akita prefecture, and is remembered (by Japanese colleagues) as having spoken Japanese more fluently than Korean and trying his best to live among the Japanese while never being fully accepted by them. ${ }^{12}$ Shin, who is described as having "worked with Japanese, recreated with Japanese, and lived with Japanese... [who] himself had become, in every aspect, a perfect Japanese person," mirrors aspects of Imamura. ${ }^{13}$ Imamura moved in Japanese literary circles, participating in the Shinkyō Arts Group [Shinkyō bungei shüdan] and the Manshū Literary Arts Association [Manshū bunwa kai]. From 1941, he became secretary of the Manshū Artist Alliance [Manshū bungeika kyōkai], a keystone of the Manshū state's propaganda bureau. There are no records or traces of his activities following Japanese defeat. As an ethnic Korean, he would have been denied the opportunity to (re)patriate to Japan. Imamura's contemporary, Takeuchi Shōichi, recalls thinking that "Although he wanted to become Japanese from his very heart and soul, in reality he was denied a seat on the train for repatriates. [I] thought that Imamura must have been at a loss for what to do with himself as he reflected on his position as someone who, as a non-Japanese, was mere human detritus." 14

10 Manshū no hikari to kage, 672.

$11 \mathrm{Yu}$, “'Jinmin'to 'futei senjin,", 57

12 Akihara Katsuji, "Imamura Eiji no omokage," Shokuminchi bunka kenkyū, 4 (2005): 190.

13 Imamura, "Travel Companions," 70.

14 Quoted in Okada Hideki, "Kyū 'Manshūkoku' no Chōsenjin sakka ni tsuite," Shōwa bungaku kenkȳu, 25 (1992): 54. 
Takeuchi's words invite pathos, but speak more to the imagination of the condition of ethnic minorities in Manshū in memory than to the feelings and experiences of Imamura himself, who left no direct record of those feelings in print. ${ }^{15}$

\section{Imamura in Postcolonial Context}

Several pieces of research have appeared in Japanese, Chinese, Korean, and English addressing Imamura, "Travel Companions," and the issue of ethnic identity and morality as a central issue. The somewhat careless approach to this material by some scholars at times results in the layering of new and confounding meanings into the text-or, at least the text conceived of as an expanded archive encompassing both the short story itself and the academic discourse surrounding it. What I mean by "careless" is leaving unstated the assumption that ethnicity is a natural and even perhaps biological extension of the circumstances of one's birth. Yet, as Tamanoi's analysis of postwar repatriates - especially those Japanese who married or were adopted by Chinese during the chaos of Japan's defeatdemonstrates, ethnicity and nationality are often most potently experienced as legalistic rather than biological or cultural categories. ${ }^{16}$ Furthermore, this concept of ethnicity must be historicized: Howell avoids the term when addressing Ainu peoples, as "Early modern Japanese did not see essential cultural or racial differences between themselves and the Ainu, but rather perceived Ainu identity as an expression of the Ainu's customs $(f \bar{u} z o k u)$....Customs were fluid and pliable. So too were the iden-

15 The same could be said of Akihara Katsuji's 2005 recollections, cited above, of Imamura from that time. In addition to providing an anecdote about their meeting, Akihara speculates about the internal life of an unrelated ethnic Korean acquaintance of his.

16 Mariko Asano Tamanoi, Memory Maps: The State and Manchuria in Postwar Japan (Honolulu: University of Hawaii Press, 2009), Chapter 4. 
tities and allegiances marked by them." ${ }^{17}$ It is therefore my intention to interrogate the epistemology of ethnic identity with regards to Imamura scholarship.

One partially self-aware example of the play between the ethnic identity of the scholar and her literary subject appears in Yu Su-jeong's article. The piece is written in Japanese and contains a section entitled, "A man named Jang: Imamura Eiji and "Travel Companions"” which concludes with the comment, "But I have to admit that I have viewed this text without being able to escape the preconceived notion that 'Imamura Eiji' is 'a man named Jang." 18 Yu reflexively recognizes her fixation with Imamura's identity and expresses a desire to uncover some authentic "Jang" beneath the layers of Japanification/imperialization. Simultaneously, this Korean scholar writes in Japanese, depicting her own name in kanji and converting it to katakana (Yu Sūjon ユ スージョン), just as she translates Jang into kanji張 with a furigana gloss of the Japanized Korean pronunciation "Chan" チャン. While certainly a pragmatic practice necessary for Yu's participation in the Japanese-language dominated field of Japanese literary studies, it difficult to ignore how this mirrors the layering of linguistic labels upon the assumed core identity of the Korean Imamura beneath. Additionally, there seems to be echoes of Imamura's decision - and it was most likely a decision, as Koreans writing in Japanese in the same socio-political context as Imamura were the exception rather than the rule-leading him to adopt the cultural and political capital of Japanese language (occupying a particular habitus, in Bourdieu's ter-

17 David L. Howell, Geographies of Identity in Nineteenth-Century Japan (Berkeley: University of California Press, 2005), 6.

$18 \mathrm{Yu}$, “Jinmin' to 'futei senjin'," 57, 68. The phrase "A man named Jang” might be an allusion to Ushijima Haruko's well-known literary work "A Man Named Shuku," which tells the story of Shuku Renten (Zhu Liantian), a stereotypical example of the exceptional native trope and his compassionate Japanese interloper. Ushijima Haruko, "Shuku to iu okoto," Shōwa sensō bungaku zenshū: Senka Manshū ni agaru, eds. Agawa Hiroyuki, et al, 305-321 (Japan: Shūei sha, 1964 [1940]). 
minology), ${ }^{19}$ in Yu's participation in the contemporary field of Asian studies, where publication in the dominant languages of Japanese or English often comes with both monetary and career incentives. While it may be unfair to directly compare the forces of Japanese imperialism in the first half of the twentieth century and the makeup of the field of Japanese literary studies in the 2000 s, they both do compel a translation of the self between language and writing cultures, and through that process, the constitution of a new writing subject within an uneven political field. ${ }^{20}$ Yet there remains an underlying assumption in Yu's musing - one which is crystallized to far greater extent in Wang's essay discussed below-that "Jang" or "Chan" must have existed as a core identity awaiting excavation just as a Korean Yu stands behind her Japanese writing.

Other writing in Japanese partly sidesteps the question of name pronunciation by simply offering Imamura's Korean name in kanji without the reading gloss. This is a point of intersection between Imamura and Shin Jūkin, his protagonist: for scholars working in Chinese or Japanese, both names simply appear in kanji, just as Imamura refrained from adding reading glosses to names in his literature. The pronunciation-in Korean, Japanese, or Japanized Korean - is left to the imagination of the reader.

Indeed, only one scholar appears to have addressed this issue directlyin an English language article-indicating that

...throughout the story, readers are never told how to correctly pronounce his [Shin's] name. This is because furigana revealing the phonetic pronunciation of the characters is never provided, leaving the reader to unsure [sic] if his name should be pro-

19 Pierre Bourdieu, Outline of a Theory of Practice, trans. Richard Nice (Cambridge: Cambridge University Press, 1977).

20 The same goes without saying for the global dominance of English-language scholarship, clearly a product of western colonialism. This is especially true in the field of area studies, which developed in direct consequence of western imperialism and Euro-American militarization. 
nounced in a Japanese or Korean way. ${ }^{21}$

Unfortunately, the same level of scrutiny is not applied Imamura himself, who is introduced as "a Korean writer named Chang Hwan-gi, known by his Japanese name, Imamura Eiji...."22 Perhaps this distinction is drawn from Imamura's adoption of a clearly Japanese name, versus Shin's recognizably Korean one. On the other hand, Stephen Poland offers yet another orthographic permutation in his brief but skillful reading of the story by introducing Imamura only parenthetically as "Chang Hwangi," whereas discussing Shin only in Romanized Korean, as "Sin Chunghŭm."23

\section{The Name Order and Cultural Policy}

The problem of Korean names under Japanese dominion must be contextualized historically. The cabinet of the colonial Chōsen governor general Minami Jirō enacted a policy, spearheaded by Shiobara Tokisaburō of the education bureau, called sōshi kaimei 創氏改名, sometimes referred to in English as the "Name Order," in 1938. ${ }^{24}$ This term is a compound of two words meaning "to establish surnames and change given names." 25 While at first glance perhaps apparently a minor point, the use

21 Osada Kazuko, "Melancholic Performative Ethnicity in Manchukuo: Korean Writer Imamura Eiji's 'The Travel Companion,"' Chūgoku tōhoku bunka kenkyū no hiroba: 'Manshūkoku'bungaku kenkyū ronbunshū, 4 (September, 2007): 137.

22 Osada, 129.

23 Stephen Frederick Poland, "Manchukuo as Method: Problematizing Nationality in Literature, 1906-1945," PhD diss., (Yale University, 2016), 255.

24 Inaba Tsugio, "Shiobara Tokisaburō kenkyū: Shokuminchi Chōsen ni okeru kōminka kyōiku no suishinsha," Daigakuin Kyōikugaku Kenkyū Kiyō, 1 (1999): 200-201.

25 Takashi Fujitani, "The Masculinist Bonds of Nation and Empire: The Discourse on Korean 'Japanese' Soldiers in the Asia Pacific War," Senri Ethnological Studies, 51 
of shi for "surname" is important. Such name changes altered the family system from a recognition of blood relations ( $\mathrm{sei}$ 姓) to the Japanese, family registry-based $s h i$ (or uji 氏). This was theorized as a tool of Korean modernization and control, creating individualized identities for imperial subjects. Its nuanced application simultaneously weeded out both names incomprehensible to Japanese speakers and those too similar to native Japanese monikers, thus reinforcing Korean alterity within a linguistically unified order. While the Name Order was introduced beginning in 1938 and more strongly enforced throughout the 40s, its roots reached back to a 1912 revised family registry law. The idea fermented throughout the 1920s, awaiting the establishment of a form of the Japanese household registry system in the colony compatible with the proposed changes. ${ }^{26}$

Social enforcement of the Name Order in Chōsen began on February 2, 1940, but without widespread coercive efforts, very few Koreans initially changed their names. Name changing was not mandated by law, but was ultimately enforced through public shaming, threats, and violence. Among some converts were those who felt liberated from the stringent traditional Korean social organization. And, indeed, there are some contemporary accounts of Korean supporters who viewed it as a positive move toward ethnic homogenization. ${ }^{27}$ Such sentiments aligned with the colonial governmental line, represented by slogans such as "shared ancestors, shared roots" [dōso dōkon] and "Japan-Chōsen as one" [Nai-Sen ittai.${ }^{28}$ This theory of shared lineage between Japan and Korea was spun into a rationalization for imperialization. The influential theorist Hoshino Hisashi, whose ideas about shared lineage matured during the last decade

(March, 2000): 144.

26 Masaaki Aono, "Chōsen Sōtokufu no 'sōshi' kōsō: 1920 nendai wo chūshin ni," Momoyama Gakuin daigaku Sōgō Kenkyūjo Kiyō 28, no. 2 (2002): 187-198; Hyong Cheol Lee, "Shokuminchika no Chōsenjintachi," Nagasaki Kenritsu Daigaku Kokusai Shakai Gakubu Kenkyū Kiyō, 3 (2018): 2-3.

27 Fujitani, 144-5.

28 Lee, 5. 
of the twentieth century, argued that "the race and the language of Japan and Korea were the same" during the time of mythical prehistory, and that "the two countries were originally a single, undivided region." ${ }^{29}$ Likewise, Kanazawa Shōzaburō argued in 1910 that "the relationship between Japanese and Korean is the same as that between Japanese and the Ryūkyū dialect" ${ }^{30}$ If the Korean people were actually one and the same as the Japanese, then they would be expected to naturally join the empire and reclaim their "shared" language.

This is all to say that, in the case of colonial Korea, the social enforcement of Japanized naming conventions was one facet of a broader mass of policies and discourses justifying occupation and suggesting a horizon of assimilation of Korea into Japan. Changing family names to kanji entailed both legal and cultural restructuring of society. But what of a society that was, in theory and in the eyes of its leaders, a cultural tabula rasa?

The case of Manshū under Japanese dominion is intriguing not merely because of the immensity and complexity of the project, but also because of the breadth of its ideological adherents. The zeal some participants felt for the Manshū project was surely genuine, but much of said enthusiasm was the product of intense and sustained propaganda campaigns and cultural control. The war of cultural persuasion was carried out through the offices of the South Manshū Railroad Company (SMR) beginning as early as the 1920 s through the creation and strategic screenings of "culture films." 31 The Concordia Association [kyōwakai] took up the mantel as head of Manshū state propaganda in 1932, and in 1937 membership in the Concordia Youth League was mandated for all young adults. ${ }^{32}$ The Association touted cultural harmony among a diverse ethnic population, Pan-

29 Quoted in Oguma Eiji, A Genealogy of 'Japanese'Self-images, trans. David Askew (Melbourne: Trans Pacific Press, 2002), 67.

30 Quoted in Oguma, 74.

31 Hanae Kurihara Kramer, "Film Forays of the South Manchuria Railway Company" Film History 24, no. 1 (2012): 97-113.

32 Prasenjit Duara, Sovereignty and Authenticity: Manchukuo and the East Asian Modern (Oxford: Rowman \& Littlefield Publishers, 2003), 73. 
Asianism, and traditional Confucian values while simultaneously acting as a civilian appendage of the Japanese Kantō Army.

Assuming Imamura Eiji was born in 1911, his birth would have predated both the earliest Korean sōshi surname-change movement and SMR's earlier cultural propaganda campaigns. On the other hand, he came into the world a scant six years after Japanese annexation of the Korean peninsula and in an era in which Manshū seemed to offer Koreans some of the liberty lost in their homeland. Without knowing more of Imamura's backstory, it is impossible to know what circumstances led him to leave Korea (if, indeed, he was even born there), adopt a Japanese name, and work entirely within a Japanese-language milieu in Manshū. One may speculate that, an occupied Korea and Manshū moving toward Japanese domination afforded Imamura's cultural adaptation. Yet, as we shall see, he not only affirms the cosmopolitan dream of Manshū (in reference to the city of Dairen), but also critiques the superficial sloganeering of the Concordia Association in his literature.

\section{"Authentic" versus "Artificial" Identity}

Thus, Imamura's (and Shin's) problem of identity was not merely limited to their names, and Wang's article tackles this issue bluntly. Unfortunately, he problematically does not cite Yu's work, published 14 years earlier, despite treading a significant amount of identical analytical ground, and his understanding of identity and how it applies to his interpretation of Imamura's work is severely lacking in nuance. One illustrative example stems from what is perhaps a typo, yet poetically gestures toward his broader perspective. The paper was published with an English title and abstract appended after the bibliography. There, the title is translated as "The Resistance by Literature : The Renationalization of The Korean in Manchukuo-Take the Novel of 'The Accompanier' by Imamu- 
ra Eiji as an Example [sic]." ${ }^{33}$ The term in the Japanese title Chōsen minzoku, more conventionally translated as "Korean ethnic group," is here translated as "The Korean." The inclusion of the definite article and double capitalization suggests a reification of ethnicity into a discrete discursive object.

What is "The Korean" to Wang? He describes how Shin's attempts to "become a Japanese person by design" aim at "experiencing an artificial 'ethnic reformation"' resulting in the existential crisis at the story's outset. The "artificial[ity]" of the protagonist's (and presumably, by proxy, Imamura's) identity is derived from Wang's claim that "It goes without saying that identity is constructed via blood and land relations more than anything else. Based on those relations, a spiritually/psychologically consistent ethnic identity is formed through language...." 34 This essentialist interpretation of identity, although perhaps intended to remark upon the inability of ethnic Koreans to find social parity in Manshūkoku even amidst the assimilationist rhetoric of the Concordia Association, seems to play into popular discourses of ethnic identity as a genetic, inalienable, and endemic attribute.

To others, "The Korean" is interpreted as a problem of nationality, rather than genetics. One scholar avers that "some writers harbored desires to live as Japanese and even hid that they were Korean. They include Imamura Eiji, who denied his Korean nationality and pretended to be Japanese...."35 This striking assertion is made without any contextualization or citation, aside from the fact that Imamura is the only writer referenced in the chapter known by his Japanese name. ${ }^{36}$ In addition to attempting to

33 Wang Qing, "Bunteki na teikō: Manshū ni okeru Chōsen minzoku no saikōchiku," Higashi Ajia Nihon Kenkyū, 4 (September 2020): 173.

34 Wang, 166-7.

35 Kim Jaeyong, "Modern Korean Literature and Manchukuo," in Manchukuo Perspectives: Transnational Approaches to Literary Production, eds. Annika A. Culver and Norman Smith, 285-293 (Hong Kong: Hong Kong University Press, 2019), 291.

36 One conjectures that this statement might be in reference to the Takeuchi Shöichi 
mindread its subject, it muddies any distinction between "nationality" and ethnic identity or ethnic nationalism. The "denial" of Korean nationality implies it as an a priori identity, rather than as performative or even phenomenological. The charge that Imamura "pretended" to be Japanese further conflates Japanese ethnicity and Japanese nationality, both of which were complicated by contemporary ethno-nationalist discourses and continental policies, including surrounding the assimilation/imperialization of the Korean colony. ${ }^{37}$ I rather point to Xie's supposition that "Although [Imamura] had never been to Japan, based on his ideological colonial education, he absolutely naturally felt that he was Japanese." 38 This gesture toward "feeling" [kanjiru] signals Imamura's internal or sentimental narrative. As Uchida Jun argues, "colonialism operated not only through the state ruling apparatus but also in the realm of the unconscious...where even children and naïve adolescents could participate in colonial domination through deeply ingrained habits of thought...language use...and sentiment." 39

This is not the only charge of Imamura being a pretender. Kimberly Kono references "Travel Companions" several times on the topic of performing ethnicity in Manshū. ${ }^{40}$ Specifically, the story and its author are given as examples of a Korean "passing" as Japanese. Kono writes of her

quotation above, but there is no such indication in the article itself.

37 See, e.g., Oguma Eiji, A Genealogy of “Japanese” Self-images, trans. David Askew (Melbourne: TransPacific Press, 2002).

38 Emphasis added. Xie Qiong, "Manshū kontekusuto ni okeru izoku dōkō monogatari: Abe Kōbō Kemonotachi ha kokyō wo mezasu to Imamura Eiji 'Dōkōsha' wo rei ni," The Fifth Annual Conference of "East-Asia Colonialism and Literature Association" \& The colonialism and cultural interaction among Taiwan, Manchuria and Korea, 93-108, trans. Haneda Asako (Japan: 2018): http://hatano.world.cooc an.jp/kaken3/18sympo/sha/sha-j.pdf, 2.

39 Jun Uchida, "A Sentimental Journey: Mapping the Interior Frontier of Japanese Settlers in Colonial Korea," The Journal of Asian Studies, 70, no. 3 (August 2011): 726.

40 Kimberly T. Kono, Romance, Family, and Nation in Japanese Colonial Literature (New York: Palgrave, 2010), 33, 38. 
use of the term: "many colonized subjects attained a level of 'Japaneseness' through language proficiency and 'modern' Japanese clothing. Masquerading as Japanese facilitated access to privileges and resources reserved for the colonizing Japanese and transformed interpersonal relations...such a façade...was a concern of some Japanese colonial officials...."41 While performativity is a compelling framework to approach the problem of Imamura, Kono's language of "masquerading” and "façade" recalls to a degree Yu's implied authentic ethnic identity. There is something similar too to Wang's comment describing Imamura in contrast to ethnic Koreans who wrote in their native tongue: "In other words, he-a Korean writer-composed exclusively Japanese language works under a Japanese penname." 42

The suggestion that Imamura is a "penname" compels us to consider the perspective of contemporary readers: were they even aware of Imamura's ethnicity? To what degree was he "passing," on the page and off? I might offer two relatively straightforward interpretations of this "penname." First, following $\mathrm{Yu}$, is that it is a form of inauthentic selfrepresentation; that "Jang" uses the name "Imamura Eiji" as a false moniker to obfuscate or protect his "true" identity, constituting a "façade" which surely enabled Imamura greater cultural capital in the Manshū state. Perhaps, as Kim suggests, he used a penname to "hide" his Korean ethnicity.

I am more intrigued by a second possibility: that ethnicity can be created through performance, e.g., writing. This idea is explored in Osada Kazuko's paper entitled "Melancholic Performative Ethnicity in Manchukuo." Her central thesis is that "Manchukuo as a multiethnic state is a discursive creation rooted in an essentialized ethnicity in a way that had not existed before." ${ }^{43}$ Although she fails to fully demonstrate the historical uniqueness of this performative ethnicity, she argues convincingly that

41 Kono, 33.

42 Emphasis added. Wang, 163.

43 Osada, 129. 
"Travel Companions" enacts the struggle to perform, and in doing so, formulate ethnic identity. ${ }^{44}$ She terms this ethnic performance "melancholic," following Butler's borrowing from psychoanalytic theory, wherein melancholy is a form of failed mourning for a lost imaginary object. Imamura and his in-story doppelganger are unable to grieve the loss of Japanese identity, to which they have been systematically culturally denied. ${ }^{45}$

\section{"New Womb," New Perspective?}

Imamura published another story in 1939, half a year after "Travel Companions" in very same pages of Mansh $\bar{u}$ Administration. ${ }^{46}$ In his brief introduction to the work, Nishida claims it a "masterpiece of Manshū literature superior to ['Travel Companions']," although I don't share his sentiment and it has not enjoyed any comparative level of recognition to date. ${ }^{47}$ "New Womb" tells the story of Kin Sanboku (Kim Sang-bok), a Korean landowner, and his attempts to produce a male heir to his material wealth.

The story begins with Kin awaiting the birth of a child, the latest addition to his expansive family. Buoyed by a spirit medium's assurance that the baby will be a boy, he promises to relieve an old debt carried by one of his Chinese tenant farmers (known only by the name of her late Korean husband, Kyo/Heo) by allowing her daughter to marry his younger brother, Sanjun (Sang-jun). The debt was incurred by Kyo, who absconded with the money to join the "lawless Koreans." But the baby is born a girl,

44 Osada, 130-131.

45 Osada, 136-138.

46 All references here come from its 2005 republication in Imamura Eiji, "Shindai," Shokuminchi bunka kenkyū, 4 (2005):199-220.

47 Nishida Masaru, "Imamura Eiji no naishin no sekai: 'Shindai' no kaidai wo kanete," Shokuminchi bunka kenkyū, 4 (2005): 191-198. 
dashing Kin's hopes for a direct heir to his fortune. He despises the idea of leaving everything to Sanjun, a "workhorse" who has carried the burden of physical labor for his older sibling. Kin has been unable to engage in physical labor ever since losing a leg to a stray bullet during an altercation between Japanese and Chinese soldiers. As the elder brother, Kin traditionally controls Sanjun's fate, and is only willing to grant permission for marriage after securing a male heir for himself.

Time passes, and the latter half of the story touches on the internal tension developing in Kin's expansive family, including the evolving politics between his two concubines and first wife. Sanjun, driven to his wit's end by his elder brother's suffocating leash, discovers himself one day lying exasperated in a field when a pair of dragonflies alight on his chest. The male dragonfly approaches the unsuspecting female from behind and forces itself on her. Sanjun interprets this copulation as a positive example of natural relations. He follows its cue, departing for the tenant farmer's plot to take her daughter, Hideka (Yinghua, Yeong-hua), as a bride. He gets her attention by violently striking her on the head, causing her to chase him into a field of kaoliang (native sorghum), inside which they, in the author's neutrally-worded description, follow nature's example.

When these events come to light, Kin becomes apoplectic. He demands the debt be repaid in full before the marriage is formalized and the financial obligation dissolved. Sanjun moves into his beloved's home to take care of her aging mother, who immediately recognizes the young couple's marriage. The story closes with two new pregnancies: Kin's new child, to be born under the portent of a dream of the rising sun; and Sanjun and Hideka's, heralded by a dream of a dragon.

Unlike "Travel Companions," nearly every character is named, but still none are given pronunciation glosses. The narrator and characters of "New Womb" offer a good deal of moralizing commentary on the developing plot and extra-literary context. Kin lambasts the Concordia ideals of ethnic harmony in Manshū (rattling off the buzzwords Man-Sen $y \bar{u} w a$, gozoku kyōwa, and Nichi-Man ittai) when they conclude in a potential 
marriage between his Korean brother and Chinese peasant - and the cancellation of the debt. ${ }^{48}$ Failure of ethnic harmony is also indirectly implied in the split between the Korean Kyo and his Chinese wifealthough this is countered by the later successful union of her daughter and Sanjun. The narrator waxes lyrically, comparing harvest time to war, remarking upon nature's indifference to succession, land ownership, or other human concerns. When we die, we all return to the earth's bosom. ${ }^{49}$ Sanjun ponders that by claiming land, human values become twisted, leading to conflict, the development of weapons, and the loss of freedom. Conversely, the human ideal should be an "innocent" or "naïve" [mujaki] lifestyle. ${ }^{50}$ The author's appraisal of a naturalistic lifestyle also connects with human bodies and health. Of Hideka, he writes that she was "eighteen years old, her limbs had grown long and healthy from working in the fields, and the flesh hidden beneath her thin kimono was resilient."51 Several pages later, the frail, damaged body of Kin is unfavorably juxtaposed with Sanjun's "hardy physique." 52 Kin's infirmity is also generally used to symbolize his impotence throughout the story.

"New Womb" differs from "Travel Companions" in several important ways, not the least of which is a greatly expanded cast of characters with differing motivations and perspectives, or the omniscient narrator flitting back and forth between multiple perspectival characters. Rather than an overarching concern with nationalism and ethnic relations, this story is more explicitly critical of the class structure and quasi-feudal economy which marked much of rural Manshū society. It is no coincidence that the opening line introduces Kin flipping a coin to determine the sex of the coming child. The coin here reflects his preoccupation both with material

48 Imamura, "Shindai" [New Womb], 207.

49 Imamura, "Shindai" [New Womb], 211-212.

50 Imamura, "Shindai" [New Womb], 219.

51 Imamura, "Shindai" [New Womb], 213.

52 Imamura, "Shindai" [New Womb], 218. 
wealth and the specific issue of succession. ${ }^{53}$ Further, the story offers a high-minded critique of war, violence, and modernism through appraisal of nature and hard-working bodies. It is not difficult to read a critique of the Manshū Incident or Manpōzan Incident into this piece.

\section{Convergence and Divergence between "Travel Companions" and "New Womb"}

The philosophical standpoint concerning nature and physicality in "New Womb" seems distinctly at odds with Shin's values in "Travel Companions," according to which "primitive" farm life was a forbidding and hollow existence. Perhaps this is because Imamura prefaces the entirety of "Travel Companions" by distancing himself from Shin's consciousness, whereas the narrator of "New Womb" seems to speak from a standpoint rather close to the younger brother, Sanjun. The idiosyncratic opening lines of "Travel Companions" read:

(- the protagonist of this short story...Shin Jūkin's way of life has already struck an impasse. Or, at least, he himself is forcefully under that conviction. Either way, I would appreciate it if you understood that as you read this story. Perhaps, one might complain that they simply don't understand his position. But the protagonist himself is strictly convinced of this fact, and from his perspective, he is absolutely at an impasse, and the author of this work is in no position to give an expedient rationalization- -$)^{54}$

$\mathrm{Yu}$ interprets this as a deliberate process of dividing the "real author" from the "implied author," "narrator of the prologue," "narrator," and the

53 Imamura, "Shindai" [New Womb], 199.

54 Imamura, "Dōkōsha" [Travel Companions], 68. 
character Shin himself. ${ }^{55}$ By enclosing this comment in parentheses and professing a lack of understanding of Shin's internal state, Imamura attempts to distance himself as author from both the character of Shin and the character of the narrator of the story, who speaks almost exclusively from the perspective of the main character. Yu concludes that this effectively (1) separates the parenthetical writer from the narrator, (2) helps transition the reader of 1938 to the historical moment of 1931, and (3) gesture toward the lack of an objective perspective. ${ }^{56}$ Contrast this, then, with the much more conventional "New Womb," in which the omniscient narrator ping-pongs between Kin and Sanboku's perspectives.

This begins to answer part of the question I initially raised concerning how Imamura's literature operates as, in Kitamura Kenjirō's parlance, a piece of "production literature" - if perhaps the answer is partly "inconsistently." We can pursue this further by looking at the stories' resolutions. The nuance of the final lines of "Travel Companions" are critical to the reading of the story overall, and so I reproduce them here at length:

Shin Jūkin was gradually overcome by an incomprehensible boiling rage. He pinned down his travel companion using his every ounce of strength until he was able to pry the pistol from his hands. As the man frantically struggled against him, Shin howled,

"Don't make a move, or I'll shoot you goddamn first!"

The luggage carts [that the two men were riding] had drawn close enough to the eight men ahead that their faces could be clearly differentiated.

Shin Jükin rubbed away the tears filling his eyes with a fist, firmly gripped the pistol at the ready, and glared at the approaching eight men.

A magpie was crying out from the top of a willow tree. ${ }^{57}$

55 See, e.g., Yu, 59-60.

$56 \mathrm{Yu}, 60$.

57 Imamura, "Dōkōsha" [Travel Companions], 82. 
These lines crystallize Shin's liminality in a way Osada and Poland interpret through Shin's subjectivity, or lack thereof. Osada argues that "Shin fails to constitute his subject both as a Korean and the Japanese [sic] and becomes what Agamben calls homo sacre," "a person expunged from society and deprived of all rights and functions in civil religion, someone who can be killed without the killer being regarded as a murderer...." 58 For Poland, Shin's "imperative to act despite the double bind of his position signals the emergence of a subjectivity temporarily tied to the state of Manchukuo's establishment in the context of the story's setting." 59 Shin's physical position in the northern reaches of Manshū beyond the direct control of the Japanese military and temporal setting on the eve of the establishment of the Japanese puppet state of Manshūkoku reflects his occupation of the gray zone of homo sacre. On the other hand, if we read the story as Poland does with an eye to the fiction's future anterior - knowledge of the status quo in the mind of the reader in 1938-we can see the anticipation of a legal subjectivity contingent upon the establishment of Manshūkoku and the discourse of ethnic harmony to develop over the next half decade.

Wang's reading of this final scene hinges on the final line of the story, which was added in the Manshū Roman publication. He interprets the sound of the magpie singing in a way which clashes with these other interpretations. He claims that "this inconspicuous final line is of the utmost importance" and changes the "open-ended" nature of the story into "a truly unambiguous conclusion." $60 \mathrm{He}$ offers two reasons. First, that the sound is of the singing bird indicates that Shin has not discharged his firearm. Second, that the magpie has historical connections with the Korean peninsula and ought to be considered a sign of Korean nationalism. In other words, Wang rejects any sense of ambiguity, and suggests that Shin has fully embraced his authentic ethnic identity.

58 Osada, 142-3.

59 Poland, 159.

60 Wang, 168. 
Regardless of which reading one finds most convincingly argued, it is clear to me that their conclusions all stand on the location of northern Manshū, and its perceived status as beyond Japanese state control. The imagination of northern Manshū, stretching into Mongolia (sometimes represented by the portmanteau "Man-Mō") as a vast and wild wasteland can be observed across a breadth of Japanese-language literature in Manshū. In "Travel Companions," Shin equates northern Manshū and agricultural work with a "primal, barbaric way of life."61 This is a semiotically dense comment, invoking notions of racial alterity, classism, and cultural hierarchy. The invocation of the "primal" [genshi teki] denies coevalness to the frontier region. This is what Fabian refers to as the "spatialization of time" by which the anthropological object is othered through both geographic distance and a chronological discourse. ${ }^{62}$ The people inhabiting such spaces in the Japanese empire were labeled "savages" and even categorized according to different levels of "savagery" based on their proximity to Japanese culture. ${ }^{63}$ Closeness to Japanese, urban, and cosmopolitan culture was contemporarily associated with a higher "cultural level" [mindo]. It was the duty of Koreans such as Shin to educate themselves in Japanese ways and improve their cultural level. ${ }^{64}$

It bears noting that the semiotic map of Manshū was more detailed than a simple binary of center/periphery. Japan's foothold in the region began early in the $20^{\text {th }}$ century with the port city of Dairen and city of Hōten (Fengtian/Mukden/Shenyang), both proximal to the Korean peninsula. Only after the Manshū Incident was the capital city of Shinkyō aggressively developed in the north. The "north" referred to in "Travel Companions" is beyond the reaches of the capital. Thus, one view has divided the

61 Imamura, "Dōkōsha" [Travel Companions], 71.

62 Johannes Fabian, Time and the Other: How Anthropology Makes its Object (New York: Columbia University Press, 1983), 13.

63 Robert Thomas Tierney, Tropics of Savagery: The Culture of Japanese Empire in Comparative Frame (Berkeley: University of California Press, 2010), 7-8.

64 Christina Yi, Colonizing Language: Cultural Production and Language Politics in Modern Japan and Korea (New York: Columbia University Press, 2018), 18. 
Japanese literary community between the representative literary journals Sakubun (est. 1932) in the south and Manshü Roman (est. 1938) in the north. Southern writers supposedly had longer roots on the continent and were more critical of the Manshū project, whereas northern writers were more likely to have immigrated after the founding of Manshūkoku and were more vocal in their patriotism. ${ }^{65}$ This overly simplistic model has been challenged, especially when recognizing the heavy overlap in contributors to both publications. ${ }^{66}$ Either way, southern Manshū was more often portrayed as a cosmopolitan hub containing a mixture not only of East Asian inhabitants, but white Russian refugees, British missionaries, etc., whereas Shinkyō was the seat of the Japanese puppet government and face of the Manshū state.

Imamura's Shin has integrated into this multi-ethnic state to the best of his ability and found a fruitful life in the cosmopolitan hub of Dairen. His "impasse" forces him to temporarily relocate to Chōshun enroute to the northern reaches. In doing so, his struggle seems to clarify into a binary opposition between the Japaneseness of (soon-to-be) Shinkyō and the Koreanness of the outlands. Shin himself recognizes this as an opposition between civilization and primitivism. He clearly disdains leaving southern Manshū, seeing it as an eviction from the modern, Japanese-run ideal, to a backward, rural, subaltern space. In addition, while Shin's background is left ambiguous, we can surmise from his aversion to physical labor that he is also leaving the middle class. His refusal of his travel companion's offer of cash for protection, and easy assumption that he could merely pay off their assailants with the money in his wallet seem to imply that Shin is concerned less with dinner-table economic matters than his social standing in the world. ${ }^{67}$ But it is clearly the cosmopolitanism of the south in which he found acceptance, versus the lip-service "ethnic harmony"

65 Nishihara Kazumi, Okada Hideki, and Nishita Masaru, "Zadankai: Futatsu no 'Geibun,"' Shokuminchi Bunka Kenkyū, 3 (2004): 2-23.

66 Kono, 131-132.

67 Imamura, "Dōkōsha" [Travel Companions], 78, 80. 
propagated by the Concordia association in the north.

If "Travel Companions" presents a collision between Shin's assumed ethnic Korean thesis and his Japanese-imperialized antithesis, the resulting synthesis is left inconclusive as the story ends before the physical encounter with the Korean "bandits." Osada plainly spells out the contradiction of "the undecided identity of the protagonist: he is both Korean (by blood) and Japanese (by colonization), yet his identity as either is ambiguous and insubstantial." 68 Poland reads it as an example of Manshū literature's affective sensibility, arguing that the micro-political interactions these stories portray

facilitate explorations of the [situation's] potentialities' contours as they take form through the affordances of the literary text, presenting a space of temporal in-between-ness where the indeterminacy of subjectivities...can be worked out in a way that focuses on the sense of a shift in relations preceding the capture of consciousness, identity, and structure. ${ }^{69}$

Similar might be said of the conclusion to "New Womb": Kin looks forward to the ascendant (Japanese) rising sun, whereas Sanboku is spurred on by the image of a (Chinese) dragon. Here, the reader is clearly supposed to sympathize with Sanboku's perspective as the hardworking and put-upon younger brother, yet the lack of resolution-the sex of the babies, and therefore likewise the fate of the land and riches, remain undetermined - is shared with "Travel Companions." Another point the stories seem to share is the assessment of "lawless Koreans" as agents of chaos and (sometimes literal) deterritorialization. Additionally, Kin's dour appraisal of the Concordia ideals in practice may resonate with the question mark implied in Shin's affinity for southern, cosmopolitan Manshū over both the denationalized northern border and propagandistic

68 Osada, 137.

69 Emphasis added. Poland, 146. 
space of Chōshun/Shinkyō.

\section{Minor Style and Japanese-language Literature in Manshū}

I contend that these unresolved dialectics through which the writer and reader both explore the "indeterminacy of subjectivities" might be understood through Deleuze and Guattaris' treatment of minor literature. Concerned with the politically subversive, they argue that the minor is written in the dominant language while introducing strategic ambivalences. In their example of Kafka, the use of incomplete triangular relationships mimics a broken Oedipal structure, generating de-territorializing potentiality. ${ }^{70}$ The flows of desire in minor literature are polyvocal, moving both toward fascism (for Imamura, Japanese imperialism) and escape (some kind of imagined authentic life), between poles of immanence and transcendence, deterritorialization and reterritorialization. ${ }^{71}$ Whereas the literal architects of Manshūkoku depicted the land as an "empty page" awaiting territorialization via imperialization, ${ }^{72}$ the polyvocality of the minor text, and the cosmopolitanism of Manshū writing in particular, subverts that political narrative. Imamura's own inconsistency in tone and subjects reinforces this minor aspect of his style.

Consider in this light Kono's keyword of "passing" and the question of authenticity. Robertson's prior work on cross-dressing Takarazuka musical theater argues that colonial subjects attempting to pass "could only always approximate and never really become-nor should they ever become-" Japanese. She does not describe this is a failure to achieve au-

70 Gilles Deleuze, and Felix Guattari, Kafka: Toward a Minor Literature, trans. Dana Polan (Minneapolis: University of Minnesota Press, 1986), 12.

71 Deleuze and Guattari, 60-61.

72 David Tucker, "City Planning without Cities: Order and Chaos in Utopian Manchukuo," Crossed Histories: Manchuria in the Age of Empire (Hawaii: University of Hawaii Press, 2005), 60. 
thenticity, but instead as a "strategic ambivalence of assimilation." And while Imamura may represent a limited counterpoint to her claim that "Japanesized Asians...could [not] lay claim to the liberties and opportunities afforded real Japanese," her characterization of performative ethnic ambiguity as tactics helps to describe Imamura's literary praxis. ${ }^{73} \mathrm{Re}$ gardless of Imamura's relative success at "passing," and setting aside the thorny issue of "authenticity," I would argue that Imamura clearly mobilized ambiguity, and that this form of "colonial poetics" must have exerted some kind of effect - what Boehmer might describe as a precondition to resistance - in the readers' minds. Given the comparative complexity, centrality, and frankly bluntness of these themes in "Travel Companions," it is perhaps unsurprising that it has so surpassed "New Womb" in literary memory and esteem.

These various elements add up to what one might call a minor style or Japanese-language Manshū literary aesthetic. Imamura's decision not to provide reading glosses of multi-ethnic character names introduces ambivalence. The changing costumes of Shin, the Japanese man, and the "bandits," all subvert the territorialization of ethnic identity. Imamura's easy combinations of Japanese, Korean, and Manshū-Chinese language similarly seem to speak, on the one hand, to the Concordia multi-ethnic propagandistic ideal; but on the other, to a polyvocal undercutting of the de facto Japanese majority. Furthermore, the thematic elements of absent, failed, or surrogate fathers suggest an implicit critique of the emperor system or Japanese government by proxy. These stylistic and narratological choices can be observed in other contemporary literary examplessuch as throughout the 1940 anthology of writings by nine authors called Miyaohoi-constituting a pedagogical poetics, a topic which for lack of space I cannot develop here. ${ }^{74}$

73 Jennifer Robertson, Takarazuka: Sexual Politics and Popular Culture in Modern Japan (Los Angeles: University of California Press, 1998), 95-6.

74 Asami Fukashi, ed. Miyaohoi: Manshū sakka kyūnin shū. Japan: Yumani shobō, 2000 [1940]. 
In these last few pages I have attempted to outline a minor style in the writing of Imamura Eiji, and to show how the ambivalence and polyvocality of his writing had a politically deterritorializing tendency-in directions away from both Japaneseness and Koreanness. I hope it should be clear that there is a direct friction between this way of reading and his portrayals in recent scholarship which seem overly concerned with the idea of an authentic ethnic identity. If we are to engage in a postcolonial reading of literature from the Manshūkoku period, it is essential to remain cognizant of the performative play of identity and politics, both in the language of primary texts and in the position of the scholar who sets about framing them.

\section{Works Cited}

1. Akihara Katsuji, "Imamura Eiji no omokage." Shokuminchi bunka kenkyū, 4 (2005): 187-190.

2. Aoki Minoru. Manshū nite. Japan: Sakubun-sha, 1980.

3. Aono Masaaki. "Chōsen Sōtokufu no 'sōshi' kōsō: 1920 nendai wo chūshin ni." Momoyama Gakuin daigaku Sōgō Kenkyūjo Kiyō 28, no. 2 (2002): 187-198.

4. Asami Fukashi, ed. Miyaohoi: Manshū sakka kyūnin shū. Japan: Yumani shobō, 2000 [1940].

5. Boehmer, Elleke. Postcolonial Poetics: 21st-Century Critical Readings. Oxford: Palgrave MacMillan, 2018.

6. Bourdieu, Pierre. Outline of a Theory of Practice. Translated by Richard Nice. Cambridge: Cambridge University Press, 1977.

7. Deleuze, Gilles and Felix Guattari. Kafka: Toward a Minor Literature, translated by Dana Polan. Minneapolis: University of Minnesota Press, 1986.

8. Duara, Prasenjit. Sovereignty and Authenticity: Manchukuo and the East Asian Modern. Oxford: Rowman \& Littlefield Publishers, 2003.

9. Fabian, Johannes. Time and the Other: How Anthropology Makes its 
Object. New York: Columbia University Press, 1983.

10. Fujitani, Takashi. "The Masculinist Bonds of Nation and Empire: The Discourse on Korean 'Japanese' Soldiers in the Asia Pacific War." Senri Ethnological Studies, 51 (March, 2000): 133-161.

11. Howell, David L. Geographies of Identity in Nineteenth-Century Japan. Berkeley: University of California Press, 2005.

12. Imamura Eiji. "Dōkōsha." Korekushon Sensō to bungaku 16: Manshū no hikari to kage, 61-84, edited by Asada Jirō, Okuizumi Hikari, Kawamura Mintao, et al. Japan: Shūei-sha, 2012 [1938].

13. Imamura Eiji. "Dōkōsha" [Travel Companions]. Manshū roman, 1 (2002 [1938]): 61-84.

14. Imamura Eiji. "Shindai” [New Womb]. Shokuminchi bunka kenkyū, 4 (2005): 199-220.

15. Inaba Tsugio. "Shiobara Tokisaburō kenkyū: Shokuminchi Chōsen ni okeru kōminka kyōiku no suishinsha." Daigakuin Kyōikugaku Kenkyū Kiyō, 1 (1999): 185-208.

16. Kawamura Minato. Bungaku kara miru 'Manshū': 'Gozoku kyōwa' no yume to genjitsu. Japan: Yoshikawa kōbunkan, 1998.

17. Kim Jaeyong. "Modern Korean Literature and Manchukuo." In Manchukuo Perspectives: Transnational Approaches to Literary Production, edited by Annika A. Culver and Norman Smith, 285-293. Hong Kong: Hong Kong University Press, 2019.

18. Kono, Kimberly T. Romance, Family, and Nation in Japanese Colonial Literature. New York: Palgrave, 2010.

19. Kurihara Kramer, Hanae. "Film Forays of the South Manchuria Railway Company." Film History 24, no. 1 (2012): 97-113.

20. Lee, Hyong Cheol. "Shokuminchika no Chōsenjintachi." Nagasaki Kenritsu Daigaku Kokusai Shakai Gakubu Kenkyū Kiyō, 3 (2018): 111.

21. Massey, Doreen. Space, Place, and Gender. Minneapolis: University of Minnesota Press, 1994.

22. Nishida Masaru. "Imamura Eiji no naishin no sekai: 'Shindai' no kaidai wo kanete.” Shokuminchi bunka kenkyū, 4 (2005): 191-198. 
23. Nishida Taniyuki. "Manshū ni okeru Nihon bungaku no jōkyō." Sōdai Ajia Kenkyū, 23 (2002-3): 17-26.

24. Nishihara Kazumi, Okada Hideki, and Nishita Masaru. "Zadankai: Futatsu no 'Geibun."' Shokuminchi Bunka Kenkyū, 3 (2004): 2-23.

25. Oguma Eiji. A Genealogy of “Japanese” Self-images, translated by David Askew. Melbourne: Trans Pacific Press, 2002.

26. Okada Hideki. "Kyū 'Manshūkoku' no Chōsenjin sakka ni tsuite." Shōwa bungaku kenkyū, 25 (1992): 52-55.

27. Osada Kazuko. "Melancholic Performative Ethnicity in Manchukuo: Korean Writer Imamura Eiji's 'The Travel Companion.' Chūgoku tōhoku bunka kenkyū no hiroba: 'Manshūkoku' bungaku kenkyū ronbunshū, 4 (September, 2007): 129-149.

28. Poland, Stephen Frederick. "Manchukuo as Method: Problematizing Nationality in Literature, 1906-1945," PhD diss. Yale University, 2016.

29. Robertson, Jennifer. Takarazuka: Sexual Politics and Popular Culture in Modern Japan. Los Angeles: University of California Press, 1998.

30. Smith, Norman. "Postscript." In Manchukuo Perspectives: Transnational Approaches to Literary Production, edited by Smith Norman and Culver Annika A., 294-300. Hong Kong: Hong Kong University Press, 2019.

31. Tamanoi, Mariko Asano. Memory Maps: The State and Manchuria in Postwar Japan. Honolulu: University of Hawaii Press, 2009.

32. Tierney, Robert Thomas. Tropics of Savagery: The Culture of Japanese Empire in Comparative Frame. Berkeley: University of California Press, 2010.

33. Tucker, David. "City Planning without Cities: Order and Chaos in Utopian Manchukuo." In Crossed Histories: Manchuria in the Age of Empire. Hawaii: University of Hawaii Press, 2005.

34. Uchida, Jun. "A Sentimental Journey: Mapping the Interior Frontier of Japanese Settlers in Colonial Korea." The Journal of Asian Studies, 70, no. 3 (August 2011): 706-729.

35. Ushijima Haruko. "Shuku to iu okoto." In Shōwa sensō bungaku 
zenshū: Senka Manshū ni agaru, edited by Agawa Hiroyuki, et al, 305-321. Japan: Shūei sha, 1964 [1940].

36. Wang Qing. "Bunteki na teikō: Manshū ni okeru Chōsen minzoku no saikōchiku." Higashi Ajia Nihon Kenkyū, 4 (September 2020): 161173.

37. Xie Qiong. "Manshū kontekusuto ni okeru izoku dōkō monogatari: Abe Kōbō Kemonotachi ha kokyō wo mezasu to Imamura Eiji 'Dōkōsha' wo rei ni." The Fifth Annual Conference of "East-Asia Colonialism and Literature Association" \& The colonialism and cultural interaction among Taiwan, Manchuria and Korea, translated by Haneda Asako (2018), http://hatano.world.coocan.jp/kaken3/18symp o/sha/sha-j.pdf.

38. Yi, Christina. Colonizing Language: Cultural Production and Language Politics in Modern Japan and Korea. New York: Columbia University Press, 2018.

39. Yu Sujŏng. “'Jinmin' to 'futei senjin': Imamura Eiji 'Dōkōsha' ni miru minzoku/imin/teikoku." Nihongo to Nihon bungaku, no. 42 (2006): 56-70. 


\section{Remnants of Manshūkoku (Manchukuo): Imamura Eiji, Korean Identity under Japanese Imperialism, and Postcolonial Asian Studies}

This paper takes Imamura Eiji (1911-?) as a case study in developing a theory of minor literary style and pedagogical poetics in Japaneselanguage Manshū literature. At the same time, it grapples with reading Japanese-language Manshū literature with postcolonial reflexivity. Imamura Eiji was an ethnic Korean who was an active participant in the Japanese language literary community of Japan-occupied Manchuria. While he is best known for his short story "Travel Companions," this paper contends that his work and position within the Manchukuoan state can be better understood through the juxtaposition of multiple of his diverse works, including another short story entitled "New Womb." Borrowing from Elleke Boehmer's "postcolonial poetics," I approach these texts from the perspective of not merely what politics they attempt, but also how they do so aesthetically and technologically. I conclude that Imamura produced a form of minor style observable in other contemporary literary production as well. While previous work on Imamura has laser focused on decoding his ethnic politics, I argue that we must aim for a more careful and critical reading by remaining aware of the contemporary politics of the academic field and relationality between scholar and text.

Keywords: colonial literature, Manchuria, Manchukuo, Japanese literature, poetics 


\section{〈국문초록〉}

\section{만슈고쿠(만주국)의 자취: 이마무라 에이지, 일본 제국주의하의 조선인 정체성, 그리고 포스트콜로니얼 아시아학}

조슈아 리 솔로몬 (히로사키대학교)

이 논문은 일본어로 된 만주 문학에서 교육학적 시학과 소수 문학 양식에 관한 이론 을 개발하는 사례 연구로서 이마무라 에이지(1911 ?)를 조명하였다. 동시에, 탈식민지 적 성찰을 통해 일본어 만주 문학의 독법에 대해 고심하고자 한다. 이마무라 에이지는 조선인으로서 일본이 만주를 점령했을 당시 일본어계 문학 커뮤니티의 활발한 참여자 였다. 이마무라 에이지가 단편 “동행자”로 잘 알려져 있기는 하지만, “신태” 등의 단편 과 같이 다양한 작품의 병렬적 비교를 통해 그의 작품과 만주 괴뢰국가에서 그의 입지 를 이해할 수 있음을 이 논문에서 살표보고자 한다. 엘레케 뵈머의 “탈식민주의 시문 학"에 착안하여, 본고는 이마무라 에이지의 작품들이 어떤 정치적 견해를, 어떤 미학적 인, 기술적인 방법으로 시도하였는지의 관점에서 접근하였다. 본고의 결론은 이마무라 에이지가 다른 현대문학에서도 보이는 마이너한 양식을 만들어냈다는 데에 있다. 이마 무라에 대한 이전 연구에서는 민족적 정치적 관점에 대한 해석에 집중하고 있었다면, 본고는 현대 학계의 정치적 견해와 더불어 학자와 텍스트 사이의 관계성에 주의하여 앞으로 조금 더 신중하고 비판적인 독해를 목표로 해야 한다고 주장한다.

주제어: 식민지 문학, 만주, 만주국, 일본 문학, 시문학 